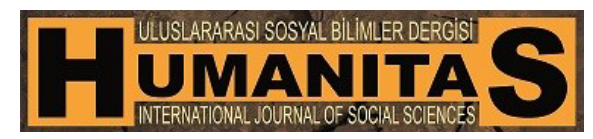

Humanitas,2018; 6(11): 115-127

ISSN:2147-0088X

http://humanitas.nku.edu.tr

DOI: $10.20304 /$ humanitas.339477

\title{
KÜÇÜREK ÖYKÜDE EPIFAN
}

\section{F.Gül KOÇSOY ${ }^{1}$}

Öz: Bu çalışma, edebi bir kavram olarak epifan ile küçürek öykü türü arasındaki ortak noktaları bulmayı ve örnek öykülerle bunları göstermeyi amaçlar. Anlık idrak, şiirsellik ve kalıcı davranış değişikliklerine yöneltme gücü, hem tinsel açılımları ifade etme araci/tekniği/deneyimi olan ve ontolojik niteliğe sahip epifanda, hem de felsefi içerikli ve açık uçlu olan küçürek öyküde mevcuttur. Epifan ve küçürek öyküde sıradan ve bilindik görünen olgular farklı boyutlarıyla göz önüne serilir ve bireysel boyutta yaşanan deneyimler evrensellik kazanır. Epifan ve küçürek öykünün ortak amacı okuyucuya yaşamın/varlığın özüyle ilgili hakikatleri duyumsatıp yeni bakış açılarını benimsetmek ve bu süreci başka deneyimler için de uygulama alışkanlığ 1 kazandırmaktır. Tıpkı diğer türlerdeki epifanlar gibi küçürek öyküde yer alan epifan da, metnin sonlandığı/kapandığı noktada okuyucuda sarsıcı bir etki bırakarak başlar, onun hızlı bir duygusal ve düşünsel süreci deneyimlemesine neden olur ve sonrasında söz konusu olay veya olguya dair yeni anlamalar, değerler ve inançlar üretip onları içselleştirmesini sağlar. Bu bağlamda küçürek öykü doğrudan epifanı çağrıştırmaktadır. Az ve öz yapısıyla kabul edilmiş gerçeklerin sorgulanması ve farklı açılarla yeniden inşasını öngörmektedir. Okur, epifan yaşayarak gerçeklerin göreceli olduğunu bir kez daha anımsayacak ve olay/olgulara farklı açılardan bakmanın yaşamı olumlu yönde etkilediğini görecektir. $\mathrm{Bu}$ ise edebiyatın temel işlevidir; epifan ve küçürek öykü bu işlevi birlikte yerine getirmektedir.

Anahtar Sözcükler: Küçürek Öykü, Epifan, Tinsel Açılım, Anlık İdrak, Göreceli Gerçek.

\section{EPIPHANY IN SUDDEN FICTION}

Abstract: This study aims at finding the common points between epiphany as a literary concept and sudden fiction genre and demonstrating them through sample stories. Epiphany which is the means/technique/experience of explaining spiritual insights has ontological feature and shares with philosophical and open-ended sudden fiction momentary perception, poetic nature and the power of leading to the permanent changes in behaviours. Both in

${ }^{1}$ Dr. Öğr. Üyesi, Fırat Üniversitesi, İnsani ve Sosyal Bilimler Fakültesi, Batı Dilleri ve Edebiyatları Bölümü. fgulkocsoy@firat.edu.tr. 
epiphany and sudden fiction, seemingly ordinary and known phenomena, with their different aspects are shown and the individual experiences gain universal particularity. The common purpose of epiphany and sudden fiction is to make the reader sense the truths about the essence of life/being, adopt new points of view and gain the habit of exercising this process for other experiences. The epiphany in sudden fiction, like the ones in other genres, begins at the ending/closure leaving a shocking impact on the reader. It motives her/him to experience a rapid emotional and intellectual process and to produce new understandings, values and beliefs on the particular event/phenomenon and to internalize them. In this context, sudden fiction directly reminds us of epiphany. With its concise texture, it prescribes that accepted truths should be questioned and rebuilt by new views. The reader, by experiencing epiphany, will once again remember that truths are relative and see that evaluating events/phenomena by different views affects life positively. This is the main function of literature; epiphany and sudden fiction actualize this function together.

Keywords: Sudden Fiction, Epiphany, Spiritual Insight, Momentary Perception, Relative Truth.

\section{Giriş}

Mitolojik ve dini bağlamlardaki anlamlarının yanı sıra, estetik kuramda önemli bir yeri olan epifan deneyimi, Romantik ve Modernist akımın öncüleri tarafindan anlık tinsel açılımları ve varoluşun farkına varıldığ anları (W. Wordsworth ve J. Joyce gibi) ifade etmede sıkça dile getirilmiştir. Küçük, sıradan ve bilindik görünen olguların insan yaşamında aslında önemli olduğu veya olabileceği gerçeğine dikkat çekme aracı/tekniği de olan epifan, metinlerde bireysel sınırları aşıp, toplumsal ve evrensel boyutta başka bireylerle ortak paydalar kurulmasına zemin hazırlar. Bir başka deyişle, öznel deneyim toplumsal, hatta evrensel deneyime dönüşür. Bu tür olaylardan evrensel değerlere de ulaşılır ve farklı bir bakış açısıyla bakılarak bu değerlerin yeniden ama farklı bir boyutuyla anlık sezilişi ve algılanışı gerçekleşir. Bu bağlamda epifan "[b]ir nesne, sahne, olay ya da zihnin hatırlanası bir sürecinden kaynaklanan, kendisini her ne ürettiyse onun özelliğinin veya katı mantıksal bağının dışında gerçekleşen ani tinsel bir tezahürdür” (Beja, 1971,18) ve bireysel çerçevede deneyimlenen düşünsel, duyuşsal ve duygusal deneyimleri anlatır.

Romantik, modernist ve postmodernist edebiyatta çok önemli yere sahip olan 'an'ların birçoğu da aslında epifan sınıfına girer. Bu anlar, yaşama şekil verecek kadar önemlidir, çünkü önemli ve merkezi gerçekleri fark etmek, karar vermek ve sonrasında içselleştirme sürecinde de etkili olur. 
Bilindik bir konuya yeni yorum getirmek için yazar, farklı bir bakış açısı benimsemek ve bunu okuyucuya sunmak zorundadır. İletmek istediği mesaj ile okuyucunun anladığı örtüşecek biçimde dil ve mantık oyunlarına başvurarak bu bakış açısını pekiştirip, söz konusu gerçeğin önceden düşünülmemiş boyutuna dikkat çeker. Bu gerçekler genellikle yaşamın, sevginin, ölümün, doğanın ve insan ilişkilerinin anlamına dairdir. İnsanın varoluşsal yalnızlığı, grotesk durumu, kader olgusu gibi derin ve büyük meseleler, bazen kan donduran bazen de gülümseten yeni anlamalarla göz önüne serilir. Epifanlar, insan için dünyayı anlayıp inanç formülleri ve değer üretmede ciddi, önemli ve köşe taşı deneyimlerdir. Önceden duyulan veya bilindiği zannedilen ama zihinde net olmayan bir olgu, bu deneyimle netlik kazanır ve sahiplenilir. Bilinçli olunduğu zannedilen yaşamda, kapalı (ama açı zannedilen) bir gerçeğin açımlanmasıyla, yani bu özel anlarla bilinç kazanılır. Buna bir tür üst bilinç demek yanlış olmaz. Epifan, yoruma ulaşana kadar okuyucunun metni anlamak için sarf edeceği mantıksal veya düşsel süreçlerden kaynaklanmasına rağmen, anlık bir farkındalık oluşumudur, yani bu süreçleri kapsamaz ve okumayı bitirir bitirmez zihinde oluşan bir etkidir. Kalıcı etkisi, kazanılmış ve öğrenilmiş, artık unutulmayacak olan zihinsel bir davranış şekline dönüşür ve değişik bakış açılarına hoşgörü alışkanlığı kazandırır. Epifandan sonra söz konusu olguya bakış, bilinç düzeyinde değişmiş olur.

\section{Küçürek Öykü ve Epifan İlişkisi}

Çoğunlukla postmodern dönemde sayıca artan ve rağbet gören felsefi içerikli, açık uçlu karma bir edebi tür olarak küçürek öykünün doğasına epifan rahatlıkla uymaktadır. İngilizce'de 'flash' (ani ve kısa parıldama) ve 'sudden' (ani) adlandırmalarıyla da bilinen bu tür zaten epifanı çağrıştırmaktadır. Bir taraftan postmodern durumun getirdiği sıradanlık, umutsuzluk, sıkıcılık ve sıkışmışlık hissiyle yüzleşme, diğer taraftan bu histen zaman zaman oyunsuluk aracılı̆̆ıyla anlık kopuş, uzaklaşma ve ferahlama anlarını yaşatan küçürek öyküde, olay örgüsünden çok yarım kalmışlık hissi veren ayrıntıya dayalı gerçekler ve şaşırtıcı hatta şok edici bir sonuç/kapanış ön plandadır. Epifan bu noktada, söz konusu gerçekleri atlama tahtası olarak kullanıp daha geniş bir gerçeğin/gerçeklerin ufkuna açılmak yolunda anlık aydınlanmalar ve etkiler sunar. Sıradan bir düşünce veya olay/olguyla başlayıp umulmadık biçimde biten/kapanan ve metnin gidişinden farkl1, bambaşka bir duygu ve düşünce atmosferine, yani epifana geçilir. İçsel bir itkiyle kendiliğinden ortaya çıkan bu deneyim hızlı bir zihni egzersize yol açar. Sırasıyla algı, duygu, düşünce ve anlamlandırma yer alır. Dolayısıyla, okuyucu öyküye başladığında zaten etkin olarak olayın/olgunun içindedir ve öykü düz anlamsal olarak 
bitmez; okuyucu belki bir kez daha okuyup kendi sonucuna varacaktır. $\mathrm{Bu}$ sonuç - epifan birlikteliği geniş anlamda yaşama dair olduğu için, şaşırtıcı, şok edici, belki korkutucu ve sarsıcı bir etki bırakır. Şiir gibi küçürek öykü de kısa olduğu için epifaniktir, ya da epifanik olduğu için bu kadar kısadır denebilir.

Küçürek öykülerde yazar metinde söz sahibi olmayıp sadece duygu ve düşüncelere pencere açtığından, okuyucu, metindeki anlamla baş başa/karşı karşıya kalır. Ya onunla hemfikir olacak, ya da metnin meydan okumalarına (okurun alıştığı, bildiği, kabul ettiğinin dışında kalan yorumlara) tepki vermek, cevap vermek, anlamak için durmak zorunda kalacaktır. Durduğu anda ise epifan deneyimiyle yüzleşecektir. Küçürek öykü, az ve öz yapısıyla zamanın, insan durumunun çelişkilerini olduğu kadar genel kabul görmüş bilgileri bile sorgulatır ve yeni düşünce ufuklarına ilham kaynağı olur. Estetik zevkin ve tepkinin kendiliğinden ortaya çıktığını ve anlık olduğunu farz edersek, epifanın sanattan yani küçürek öyküden felsefeye uzanan bir köprü olduğu sonucuna varırız. Estetik, güzel olanı farklı ton ve boyutlarıyla ontolojik ve epistemolojik yönleriyle deneyimleme/düşünme olduğuna göre, dikkatimizi haz boyutuyla çeken deneyimler sonrasında yargı sürecimize, değer ve tavır takınmamıza yardım eden unsur ontolojik bir kavram da olan epifan olmaktadır. $\mathrm{Bu}$ noktada edebiyatın işlevi yerine getirilir: duygulara, düşüncelere hitap edip insanda olumlu evrensel değerler ve farkındalıklar oluşturmak.

Küçürek öykü yazarı, varoluş ve aydınlanma anları olan epifan ile yaşamın özüne dair nadir olgu ve hakikatleri okuyucuya duyumsatıp fark ettirirken, nesnel zaman tünelinde bir parantez açıp mekân-zamansal o parantezde okuyucuyu ani idrak noktasına sürükler. $\mathrm{Bu}$, okuyucu açısından nesnel zamanın durması ve bir kenara bırakılması ve öznel zamanın genişlemesi demektir. Duyumsamaların gerçekleştiği bu olağanüstü ve yegâne anlarda farkındalık kristalleşip tüm yoğunluğuyla netleşir ve kendini özne içinde açımlar.

Romantik, modernist ve postmodernist akımlarla kendini gösteren epifan ve küçürek öykü örnekleri de aşağıda bu akımlardan seçilen öykülerle ve estetik kurama dayalı olarak tür eleştirisi (genre criticism) yöntemiyle ele alınacaktır. Epifan kavramı, bu öyküler üzerinden gösterilecek ve varlığı kanitlanacaktır.

\section{Küçürek Öykü ve Epifan İlişkisine Dair Örnekler}

Romantik akımın İngiliz edebiyatındaki önemli temsilcilerinden Oscar Wilde'ın (1854-1900) "Çırak" ("The Disciple"-1894) adlı çok kısa 
öyküsü, ya da düzyazı şiiri, genel kabul görmüş mitolojik bir inancı yapı bozuma uğratır:

Narkissos öldüğünde, zevk pınarı bir tatlı su havuzundan tuzlu gözyaşı havuzuna dönüştü; Oreas'lar pınara şarkılar söyleyip teselli etmek için ağlayarak ormandan çıkıp geldiler.

Pınarın bir tatlı su havuzundan tuzlu gözyaşı havuzuna dönüştüğünü görünce, yeşil saç örgülerini çözüp pınara seslendiler, "Narkissos için böyle yas tutmana şaşırmadık, çünkü o çok güzeldi," dediler.

"Narkissos güzel miydi?" dedi pınar.

"Bunu senden iyi kim bilebilir?" diye cevap verdi Oreaslar. "Bizim yanımızdan geçip giderdi hep, ama seni yalnız bırakmazdı, toprağa uzanıp sana bakar, senin sularının aynasında kendi güzelliğinin aksini seyrederdi."

Pınar şöyle cevap verdi: “Ama ben Narkissos'u, toprağa uzanıp bana baktığı zaman, onun gözlerinin aynasında hep kendi güzelliğimin aksini gördüğüm için severdim" (Wilde, 2009, 247).

Wilde, Narkissos' un bilinen öyküsünü, gölün kenarında kendi aksini görüp âş1k olması ve o arzu nesnesine kavuşamadığ 1 için üzüntüsünden intihar ederek boğulduğu yerden çıkan çiçeğe nergis denmesini yeniden ele alır ve farklı bir biçimde bitirir. Göl ile onun kenarındaki mitolojik varlıklar olan dağ perileri Oreasları kişileştirip aralarında geçen bir diyalog tasarlar. Kesin bilgi olarak varsayılan mitolojik bilgilerin bile aslında öyle olmayabileceği alt gerçeğinden yola çıkarak, aslında bütün gerçeklerin sorgulanması gerektiğini ima eder. Bize verilen, bizim de sorgulamadan ve kolaya kaçarak kabullendiğimiz bilgiler ve olgular, aslında o şekilde gerçekleşmemiş olabilir. Wilde'ın yeniden yazdığı öyküde, göl aslında Narkissos'un yakışıklılığının ve çekiciliğinin farkında değildir. Farkında olduğu şey, kendi güzelliğidir. Bu noktada, olayları yorumlarken edindiğimiz bakış açısının sorgulanması gerektiği gerçeği ortaya çıkmaktadır. Belki, şartlanmış beyinlerimiz güzel, yaygın ve güçlü olanın yanında olmayı daha rahat ve kolay bulduğu için bizler gölün bu olayda neler düşünmüş olabileceğini hiç aklımıza getirmeyiz. Oysa kendi öyküsünde Wilde, edilgen gölü etken ve konuşan bir özne konumuna çıkararak, Narkissos'u edilgen konuma indirger. Böylelikle, gerçeklerin aslında tek boyutlu ve tek açılı olmadığı gerçeğini okuyucuya gösterir. Bu çok bilindik mitolojik öyküyü seçmesi de bu gerçeği unutulmaz k1lmak istemesindendir. Herkesin sorgulamadan kabul ettiği mitolojik öyküler bile aslında doğru değilse, o zaman bireysel düzlemde yaşadığımız gerçeklerimiz ne kadar güvenilirdir? Bu durumda, Wilde'ın öyküsüyle açığa çıkarmak istediği mesaj, gerçeklerin göreceli oluşu ve farklı bakış açılarıyla farklı boyut kazanacağıdır. Bu etkileyici öykünün 
şaşırtıcı sonucuyla okur, epifan yaşayarak gerçeklere farklı açılardan bakma alışkanlığı kazanma yolunda önemli bir adım atacaktır.

Wilde'ın mitolojik bir öykünün sonunu alışılmışın dışında kapatması gibi, Modernist olan Virginia Woolf (1882-1941) da bilinç akışı tekniğiyle 1921'de yazdığ 1 "Hayaletli Bir Ev" (“A Haunted House") adlı öyküsünde geleneksel bir hayalet öyküsü beklentisini boşa çıkarır. Kendi kendine açılıp kapanan kapılar, çekilen perdeler ve hayaletler gibi gotik klişeleri içermesine karşın, öyküde Woolf bir tarafta yaşam ve aşkı, diğer tarafta ölüm ve aşksızlığı konumlandırır; çünkü ancak hayatta olanlar aşk1 yaşayabilir. Ölüm ve aşk üzerine olan öyküde anlatıc1/yazar, canlı ve anılarla dolu bir ev düşler. Alışılmış gotik öykü kalıbının tersine, hayaletli evi korkutucu değil, aşkla dolu olduğu için esenlikli betimler. $\mathrm{Bu}$ evde uzun yıllar önce yaşamış ve orayı tekrar ziyaret etmek isteyen hayalet bir çift vardır.

“ 'Onu burada bırakmıştık,' dedi kadın. 'Burada da!' diye ekledi adam: 'Üst katta,' diye mırıldandı kadın. 'Ve bahçede,' diye fisıldadı adam. 'Sessiz olalım,' dediler, 'yoksa onları uyandıracağız' " (Woolf, 2017). Evi bir şeyler aramak için ziyaret ettiklerinde anlatıcı ve eşi bu ziyaretlerin farkında olmalarına karşın korkmazlar. Yaşı çift, tavan

arasına ve bahçeye bakar. Birbirlerine aşklarını ifade ettikleri veya paylaştıkları anları aramaktadırlar: bahçede gülerken veya tavan arasına elmaları firlatırken. Onlar aradıkça tarihinde sevgi olan ev heyecanlanır, nabzı hızla artar; anlatıcı bu hizlanan nabzı duyar. Ev sanki bir hazineden bahsetmekte ve onun güvende olduğunu söyleyerek onları rahatlatmaya çalışmaktadır. Aradıkları hazine aslında bir zamanlar kendilerine ait olan ve evde bıraktıkları, şimdi de gelip tekrar görmek istedikleri ve neşeyle yaşamış oldukları aşklarıdır. Onun güvende olduğunu evin kendilerine hissettirdiği duygudan anlarlar. "Evin içinde dolaşıp pencereleri açarak ve bizi uyandırmamak için fisıltıyla konuşarak, hayalet çift neşe kaynaklarının peşinde" (Woolf, 2017). El ele tutuşup anlatıcı ve eşinin yatağının başucuna gelince bir zamanlar yaşadıkları aşka benzer bir aşkı şimdi bu çiftin yaşadığını görüp imrenirler. Ölüm aralarına cam gibi girer, birbirlerini görebilirler ama kavuşamazlar. Buna karşın aşkın ölüme rağmen sonsuz oluşunu duyumsarlar.

"Güvende, güvende, güvende," diye atıyor evin kalbi gururla. "Uzun y1llar..." diye iç geçiriyor adam. "Yine buldun beni." "İşte," diye mırıldanıyor kadın, "uyuyor; bahçede kitap okuyor; tavan arasına elma yuvarlarken gülüyor. İşte burada bıraktık hazinemizi..." Iş̧ıları, eğilip, göz kapaklarımı kaldırıyor. "Güvende, güvende, güvende," diye atıyor evin nabzı çılgınca. Bağırarak uyanıyorum: "Ah, bu mu sizin gömülü hazineniz? Yürekteki 1şık” (Woolf, 2017). 
Hayalet çiftin evde bıraktığı aşk hazinesini anlatıcı yürekteki 1şık diye tanımlamaktadır. Hüzünlü olan bu öyküde anlatıcı, hayalet karı-kocanın aradığ 1 şeyin, eşiyle kendinde olduğunu bildiklerini anlar ve onlar tarafından kıskanıldıklarını hisseder.

Epifan, birey bazında muğlak veya yüzeysel anlam(a)ları somutlaştıran bir unsur olarak küçürek öykülerde de işlev görmektedir. Yaşamımızdaki olgu ve olaylara bakışımızı yeniden düzenlemede ve sabitlemede önemli rol oynarlar. Öykünün konusu olan aşk ve ölüm herkes tarafından bilinir ama bunların gerçek doğası ve birbirleriyle olan ilişkisi ancak epifan deneyimiyle fark edilmektedir. Aşk ancak yaşarken yaşanır. Öldükten sonra istense de aransa da hatta bulunsa da yaşanamaz; öyle ki ölüler aşk1 yaşayan dirilere imrenmektedir. Woolf, onlara karşı tehdit veya korku değil, sevgi ve acıma besler; imrenme duygularını anlayışla karşılar. Yaşarken aşkın kıymetinin bilinmesi gerektiğini, çünkü yaşamın kısa olduğunu ve öldükten sonra artık keyfinin çıkarılmasının imkânsız olduğunu vurgularken, her iki çiftin de mutlu olduğunu anlatır. Anlatıcı ve eşinin birbirlerine âşık olduğunu görünce hayalet çift kendi aşklarının güvende olduğuna karar verip mutlu olmakla yetinir. Yaşayanlara zarar vermek bir yana, hazinelerinin ne kadar klymetli olduğunu onlara anlatmak isterler. Acınasıdırlar ama böylesi sonsuz bir aşka sahip oldukları için imrenilmeyi de hak ederler. Bütün bunların farkına varıldığ " "[b]öyle anlarda kaba dış gerçeklik, algılayan için bir tür aşkın anlam taşır" (Öğretir, 2005, 81) ve yaşama, aşka ve ölüme bir bütün olarak bakılması gerektiği sezdirilir.

Tigges, epifan deneyiminin şiirselliğini dile getirir; söyledikleri Woolf'un öyküsü için de geçerlidir ve dilsel anlamda küçüreğin şiirselliği epifana uygun zemin hazırlar:

Yaşamda epifanik anların oluşturduğu, sanatta kaydedilip aktarılabilen model, her insana ait deneyimin yegâneliğini olduğu kadar, bu deneyimin eşzamanlı evrenselliğini de gösterir. Sıradan şeylerin önemini fark ederek yaşamı gerçekten anlamlı bir şeye dönüştürürüz: yıldızlı evrenin merkezinde ani bir piriltı veya bir dans $(1999,35)$.

Woolf'a göre insan, 'varoluş anları'ndan (moments of being)* olan ve okunan, görülen veya tecrübe edilen bir şeyin sınırlarını aşıp daha geniş bir dünyaya, başka gerçeklikleri düşünmeye yöneldiği anda, yaşamda bulunan ya da bulunmayan aşkın kıymetini, onu yitirmiş olanların mahrumiyetine acıyarak anlar. Ayrıca, aşkları ölümden sonra bile devam eden bu çiftler saygıya da layıktırlar.

Woolf gibi Modernist olan Bertolt Brecht (1898-1956)'in "Zavall Çocuk" (1930) adlı öyküsü ise, gerçek yaşamla ilgilidir ve 'acımak' duygusunu kavramsal boyutuyla yeniden ele alır. 20. yüzyılın ilk 
yarısında başta dünya savaşları olmak üzere politik ve kültürel değişimlerin derinden etkilediği Brecht, zengin/fakir, üst sınıf/alt sınıf veya ezen/ezilen karşıtlıklarıyla ilgilenmiştir.

Yaşanan haksızlığ sessiz sedasız içine atma gibi bir kötü alışkanlıktan söz ediyordu Bay K. ve şu öyküyü anlatıyordu: Yoldan geçen birisi, kendi kendine ağlayan bir çocuğa üzüntüsünün nedenini sordu. "Sinema için iki lira biriktirmiştim, bir oğlan geldi bunlardan birisini çekip aldı elimden" dedi ve biraz uzaktaki oğlanı gösterdi. "Peki yardım çağırmadın mı?" diye sordu adam. "Elbette çağırdım!" dedi ve daha fazla hıçkırarak ağladı. "Seni kimse duymadı mı?" diye ona sevgiyle yaklaşarak sormaya devam etti adam. Çocuk "Hayır!" dedi ve hıçkırarak ağlamaya devam etti. "Daha güçlü bağıramaz mısın?" diye sordu adam. "Hayır!" diye yanıt verdi ve yeni bir umutla ona bakmaya başladı. Adam gülümsedi ve "Onu da ver o zaman" dedi ve son parayı çocuğun elinden aldı. Ve kaygısız bir şekilde oradan uzaklaştı (Brecht, 2005, 89).

Öykü haksızlığa boyun eğmenin kötü bir alışkanlık olduğunu iddia ederek çarpıcı biçimde başladığında okuyucu epifan sürecine girer. Sinema için para biriktirdiğine göre fakir olduğu anlaşılan çocuk, elinden parasının alınmasıyla haksızlığa uğramış gözükmektedir. Ortada bir haksızlık durumu varsa, haksızlık eden ve haksızlığa uğrayan da vardır. Brecht, haksızlığa uğrayana otomatik olarak hissedilen acıma duygusunu yerle bir ederek, aslında suçlunun hakkını yeterince savunmayan bu çocuk olduğunu ortaya çıkarır. Bu durumda acınacak bir kimse yoktur; kendinden güçlü bir varlık karşısında, hakkını yeterince savunmayan ve bir iki zayıf direnişten sonra pes edip ezilmeyi kabullenen biri şefkat duyulmayı da hak etmez; bilakis suçludur. Güçlü ya da zorba, güçsüz, sömürülen ya da yenilgiyi kabullenenin karşısında gücünü teyit eder ve sonraki zorbalıklar için özgüven ve alışkanlık kazanır. Bu ise, yani fakir sınıfın ezilmeyi kabullenmesi, zorba sınıfın da bunu alışkanlık haline getirmesi bireysel düzlemi aşıp toplum bazında yaygınlaşırsa durum çok tehlikeli bir boyut kazanacaktır. O halde, haksızlık karşısında daha güçlü bir tavır, daha etkin ve kararlı bir tepki gerekmektedir. Brecht, sahip olunan ahlak ve değer bilgilerini haksızlık eden, haksızlığa uğrayan ve suç üçgeninde ele alıp acımak duygusunun gerçekten yerinde olup olmayacağını sorgularken, benzer durumlar için de okuyucunun bu duyguyu gerçekten hak eden öznelere yönlendirmesi gerektiğini bir epifan olarak yaşatır. İşte epifan, böylesine etkileyici bir sonuca gelene kadarki zihinsel duygu ve düşünce mekanizmasından yardım alarak, hak, haksızlık, suç, zorba ve mağdur tipleri ve bunları kapsayan kavram olan acımak duygusunu eleştirel ve nesnel düzeyde ele alması gerektiği gerçeğini okuyucuya hediye eder. 
Gerlach, "Gerçek anlamda öykü, aktarılan olayda gerçekten neler olduğundan çok, okuru yorum yapmaya yönlendirmesiyle tanımlanabilir. Okur, kişiler ve güdüler konusunda düşünmeye zorlandığ 1 sürece ne olay örgüsü ne de iyi işlenmiş kişi ve yer duygusu önemlidir" $(1989,74)$ derken, küçürek öykülerin geleneksel anlatılardan farklı olarak anlatı ögelerinin hepsini içermek zorunda olmadığı için, okura alımlama sürecinde ciddi oranda görev düştüğünü vurgulamaktadır. Aslında bu, görev değil anlık yaşanan ve kendiliğinden gelişen bir süreçtir. Bu süreçte okuyucu metne yabancılaşmak, kendi kendisiyle, hataları ve varsa aptallıkları ve çelişkileriyle yüzleşince öyküye tepki vermek, kafasında bir yere oturtup bahsedilen olgunun anlamını yakalamak, tahmin etmek ve kendi potansiyeli ve deneyimi içinde bireysel kararlar vermek ve tavır takınmak sorumluluğunu hissedecektir. Bu his onu epifan sürecine sokup tepki üretmesine ve varması gereken yere yöneltecektir.

Postmodern dönem yazarı Herbert Edward Francis (1924-) Brecht'in aşılamaya çalıştığ ve toplumsal tepkinin doğasını ele aldığ 1 "Oturma" (1983) adlı küçürek öyküsünde postmodernist bağlamda işler. Bir Modernist olarak Brecht, yanlışların düzelmesi için çaba sarf etmeyi öngörürken, Francis postmodernist bir tavırla düzenin istense de değişmeyeceğini kabullenir. Devlet-otorite/vatandaş ilişkisinin sorunlu ve absürd olarak gösterildiği bu öyküde, "Zavallı Çocuk" "taki çaresiz gözüken çocuğun tersine, güçlü olduğu halde hakkını korumayan birey ve devlet söz konusudur. Korunan, değerli ve ayrıcalıklı bir yer olduğu anlaşılan bir evin önünde bir şey yiyip içmeden, konuşmadan ve yağmur rüzgâr demeden devamlı oturan kararlı ve esrarengiz bir çift, ev sahibi için problem teşkil etmez; ta ki komşulardan, çöpçülerden ve yabancılardan telefonlar alıp kendisine sorular sorulana kadar. Ev sahibi kendini tehdit altında ve çaresiz hisseder, öte yandan evin önündeki çift ile kuracağı diyalog veya anlaşma isteği taşımaz. Birinci derecede kendisini ilgilendiren bu konuda merakına rağmen duyarsızlığ 1 ancak çevreden tepkiler gelince sonlanır. "Kadın ve erkekten orayı terk etmelerini istedi. Yanit vermek bir yana umursamaz bir tavırla bakıp oturmaya devam ettiler" (Francis, 1986, 101). Çağırdığı polisler çifti merkeze götürür ama sabah yine aynı manzara görülür: "İkinci gelişinde polis, ev sahibine, yer olmadığı için çifti hapse atamayacağını bildirdi. Yine de 1srar edecek olursa onlar için bir yerler ayarlayacaklarını söyledi" (101). Bu cümlelerden hapse atma eyleminin emniyet güçleri tarafindan yeterince ciddiye alınmadığı ve emniyet sisteminin zaafı görülmektedir. Güvenliğin sağlanması ve sürdürülmesinin zor olduğu ve suç oranının yüksek olduğu anlaşılmaktadır; çünkü hapiste yer kalmamıştır. Çift, belki de bu durumu 
bildiği için sonunda zafer kazanacağından emindir. Ev sahibi ile çift arasında çatışma çıkmaz. Ev sahibi yine sorunu kabullenmek ve sahiplenmek istemez ve "Bu benim sorunum değil, sizin sorununuz" (101) deyince polis bunun kendi sorunları değil, adamın sorunu olduğunu ve yine de çifti alıp götüreceklerini söyler. Polis veya geniş anlamda devlet de aslında bu durumun herkesin ortak sorunu olduğunun ve görevinin farkında değildir. Oturma eylemi yıllarca sürünce, adam son çare olarak onların öleceklerinden ümitlidir ama ironik olarak kendisi ölür. Eve belediyenin el koymasına rağmen, çiftin oturma eylemi devam eder. Belediye (devlet) evin önünü terk etmelerini isteyince şehrin sakinleri bu kadar uzun süre oturmalarından sonra, evi adam ve kadının hak ettiğini belirterek belediyeye dava açarlar. İktidar güçlü olduğu halde, kendini göstermez veya haklı çıkarmaya çalışmaz; bu yüzden ev çifte devredilir. Ertesi gün başka kadın ve erkekler evlerin önünde oturmaya başlar. Burada Francis okuru bireysel tepkilerin bazen ne kadar yetersiz, toplumsal tepkilerin de ne kadar yersiz, mantıksiz ve adalet duygusu ve anlayışından yoksun olabileceği gerçeğine götürmek ister. Şehir sakinlerinin ortak karar vererek uzun süre evin önünde oturmanın evi hak etmeye sebep teşkil ettiği gibi makul olmayan bir sebebe dayanarak belediyeye dava açmaları ilginç bir toplumsal tepki olarak su yüzüne çıkmaktadır. Demek ki, her direniş veya her toplumsal tepki çoğunluğun fikri olsa da normal veya haklı değildir.

Öyküdeki karşıtlık önce birey/toplum düzleminde başlamakta, ardından toplum/devlet karşıtlığına dönüşmektedir. Çevrenin çifti önce dişlaması, sonra kucaklaması ve devlete karşı koruması şeklinde gelişen bilinçlenme, toplumun bakış açısının alışkanlığa bağlı olarak değiştiğini anlatmaktadır. Toplumsal olay ve olguların mantık dışı seyrini özetleyen öykü, "Ertesi sabah esrarengiz erkek ve kadınlar şehrin dört bir yanında evlerin önündeki basamaklarda oturuyorlardı" (Francis, 1986,102) cümlesiyle kapanır ve bu döngünün bitmeyeceğini ve çözüme ulaşmayacağını bildirir; yani yanlış olan toplumsal sistem değişmeyecektir. İçerdeki (imtiyazlı konumdaki) ölünce veya $o$ pozisyondan çıkınca dışardaki (imtiyazlı olmayan) onun yerine gelecek ama o da başka bir davranış bilmediği için aynı şeyi tekrarlayacaktır. Onlar da dışardakilere aynı bakış açısını ve davranışı sergileyeceklerdir.

Bir şeyleri elde etmenin yolunun kararlı ve sebatkâr eylem olduğu kesindir. Öte yandan, öyküde bu tür tavrın gösterildiği durum haklı bir temele dayanmadığı için okuyucu, öykünün kapandığ ${ }_{1}$ anda, yani toplumsal sistemin işleyişindeki mantıksızlığ keşfettiği anda epifan yaşayacak ve bu olumlu tavrın her duruma uygulanamayacağı alt 
gerçeğine varacaktır. "[K]1sa öykünün nasıl bittiği o denli önemlidir ki, teknik olarak kısa öykünün bittiği - yani olayın sona erip sorunun çözümünün verildiği nokta - okuyucu açısından bu çözümün ortaya çıkardığı sonuçların düşünüldüğü bölümün başlangıcı olacaktır" (Özer, 2012,106). Devlet, kanunlar, emniyet ve düzenin tehdit altında olduğu postmodern dönemdeki toplumsal haklar ve alışkanlıkların hem imtiyazlı hem imtiyazsız gruplar tarafindan yanlış anlaşıldığını sezip kavrayacak ve son öznel yargısına ulaşacaktır.

\section{Sonuç}

Küçürek öykü türü, Romantik akımla birlikte doğmuş, Modernist akımla devam etmiş ve günümüze kadar gelip postmodernist edebiyatta da yerini alarak güncelliğini sağlamlaştırmıştır. Epifan ise varlığı küçürek öyküden eskiye dayanmasına karşın, türün doğduğu zamandan bu yana, onun yapısını tayin eden ve ondan ayrılamaz edebi bir tekniktir.

Epifan, okuyucuyu yarım kalmış gibi gözüken ama o andan koparıp durumun eleştirisini ve yorumunu yapacağ 1 ve kendince öyküyü sonlandıracağ 1 bir zaman boyutuna yöneltir. Onu sonuçtaki belirsizliğe bir düzen getirmesi gerektiği konusunda güdüler ve imge ve çağrışımlarla metnin anahtar göndergelerini ona sezdirir. Yaşamın büyük ya da küçük ölçekli gerçekleriyle yüzleşme zorunluluğuyla, okuyucu üzülerek ve sarsılarak düşünecek, söz konusu meseleyi ruhunun, aklının ve vicdanının süzgecinden geçirip birdenbire gerçekleşen bir idrak anı yaşayacaktır. Yazarın okuyucuyu ulaştırmak istediği yer ile okuyucunun ulaştı̆ı yer aynı olmasa bile söz konusu kabullenilmiş olgu üzerinde düşünmek bile okuyucuya kendi benliğiyle karşılaşma imkânı tanır. İlk defa karşılaşılan gerçeklerin ilk olarak, bilinen ve bilindiği zannedilen gerçeklerin ise okuyucu tarafindan yeniden gözden geçirilmesine imkân veren epifan ile bilindik karşıtlıklar, yargılar ve basmakalıp kıssadan hisselerin mesajları alaşağı edilir. Bilinmeyen, deneyimlenmemiş ve düşünülmemiş boyutlar açımlanır. $\mathrm{Bu}$ an, kendinden çok daha geniş bir süreye gebedir; bu yüzden, epifan anının potansiyeli geniştir. Dünya herkesin deneyimleyebileceği, epifan doğurabilecek olgu, durum ve olaylarla doludur ve yaşamı değerli kılan şeylerden biri de bu deneyimlerin tadını çıkarabilmektir. İnsan olarak kendi varlığımızdaki özel güçlerden biri olarak epifan yakalama yeteneğimiz hem epifanın, hem de neden olduğu deneyimin özgünlügünü unutturmayacaktır. İşlevselliği kısa ve özlü anlatımında olan küçürek öyküde okuyucu etkin bir biçimde üretim sürecine dâhil olarak kabullenilmiş ama sorguya açik olan yaşam tarzları, dünya görüşleri, kurumlar ve anlayışların gözden geçirilmesi hatta değiştirilmesi görevini üstlenmiş bulunmaktadır. 
William James'in dediği gibi “ölü duygular, ölü fikirler ve soğuk inançlar vardır ve bunların yanı sıra sıcak ve canlı olanlar da vardır; bunlardan biri içimizde sıcak ve canlı olarak ortaya çıktı̆̆ında, her şey onun etrafında yeniden şekillenip billur bir hal alır" (James, 2014,197). Yaşama dair yeni bir bakış açısı, yeni bir anlayış ve tavır kazanıldığında ise, aslında bütün hayat zenginleşmiş olacaktır.

Epifanı verimli bir biçimde kullanan ve onunla bütünleşen küçürek öykü, günümüz postmodern çağın gerçeklerine uygundur. $\mathrm{Bu}$ çağın insanı tarafından kısıtlı zaman sorunundan dolayı küçürek öykü kısa olduğu için benimsenmiştir ve beraberindeki epifan deneyimi edebi bir zevk sunmasının yanı sıra karşılaşılan maddi ve manevi sorunlara ve var olan değerlere yeni bakış açıları gösterdiği için bu öykü türü ile birlikte güncelliğini koruyacaktır.

*Woolf'un otobiyografik makale kitabının adı.

\section{Kaynakça}

Beja, M. (1971). Epiphany in the Modern Novel. Seattle: University of Washington Press.

Brecht, B. (1930). Zavallı Çocuk. Postmodernizm ve Alımlama Estetiği. (Çev./Yazar Yılmaz Özbek). Konya: Çizgi Kitabevi. (2005).

Francis, H.E. (1986). Sitting. Robert Shapard ve James Thomas (Ed.ler). Sudden Fiction: American Short-Short Stories. (ss.101-102) Salt Lake City: Gibbs-Smith Publisher.

Gerlach, J. (1989). The Margins of Narrative:The Very Short Story, the Prose Poem and the Lyric. S.Lohafer and J.E. Claren (Ed.). Short Story Theory at a Crossroads (ss.74-78). Louisiana: Louisiana State UP.

James, W. (1917, 2014). The Varieties of Religious Experience: A Study in Human Nature (The Project Gutenberg E-Book)

http://www.gutenberg.org/license (26.April.2017) New York: Longmans, Green, And Co.

Öğretir, İ. (2005). Edebiyatta Epifan: Sherwood Anderson'ın Winesburg Ohio'su. Konya: Çizgi Kitabevi.

Özer, S. (Nisan/Mayıs 2012). Kısa Öyküde Mitleştirme Dili. Dünyanın Öyküsü, 2, Heyemola Yayınları: İstanbul. 106-112.

Tigges, W. (ed). (1999). Moments of Moment: Aspects of the Literary Epiphany. Atlanta: Rodopi.

Wilde, O. (2009). Bütün Masallar Bütün Öyküler. İstanbul: Türkiye İş Bankası Yayınları. 


\section{Woolf, Virginia ("A Haunted House")}

http://ebooks.adelaide.edu.au/w/woolf/virginia/w91h/chapter1.ht $\underline{\mathrm{ml}}$ (20 April 2017) 